\title{
Molecular Identification of Rhizobium Isolates Nodulating Faba Bean Plants in Egyptian Soils
}

Abdel Fattah El-Zanaty, Khalid Abdel-lateif* and Mohamed Elsobky

Department of Genetics, Faculty of Agriculture, Menoufia University, Shibin El-Kom, Egypt

\begin{abstract}
Eleven isolates of Rhizobium leguminosarum symbiovar. Viciae were isolated from root nodules of Vicia faba $\mathrm{L}$. cultivated in 11 fields and represent different governorates in Egypt. The genetic diversity among the isolates was studied using the 16S rRNA gene partial sequence. The phylogenetic analysis formed two groups of isolates and the values of genetic distances were variable among the studied isolates. The highest value of genetic distance was between the isolates RL6 of North Sinai and RL8 of Dakhalia, while the lowest value was between isolates RL9 of Giza and RL10 of Sharkia. The isolates were evaluated for their tolerance to heavy metals using concentrations of $0.5,1$ and $2 \mathrm{mM}$ of heavy metals ( $\mathrm{Cu}, \mathrm{Pb}$ and $\mathrm{Zn}$ ). The ability to resist the heavy metals decreased with increase in concentration. At the highest concentration ( $2 \mathrm{mM}$ ), No growth was obtained with addition of $\mathrm{Zn}$ and $\mathrm{Mn}$ to the growth media, however only $27 \%$ of isolates could survive with the same concentration of $\mathrm{Pb}$.
\end{abstract}

Keywords: Rhizobium; Legumes; Heavy metals

\section{Introduction}

The Legumes are the third largest family of higher plants with more than 650 genera, 18.000 species and are second in agricultural importance [1]. Legumes are grown on approximately $250 \mathrm{Mha}$ and able to fix about $90 \mathrm{Tg}$ of $\mathrm{N}_{2}$ per year as result of symbiosis with Rhizobia [2]. Rhizobia are diverse group of eleven genera of Gramnegative unicellular soil bacteria which are able to induce nitrogenfixing nodules on the roots of leguminous plants as Vicia faba L. The symbiosis between Rhizobium and legumes species is very important and accounts for $50 \%$ of 175 million tons of total biological nitrogen fixation used in agriculture. The Rhizobium leguminosarum symbiovar. Viciae is among fast-growing rhizobia and able to nodulate Vicia sativa and Pisum sativum [3].

Many papers focused on the genetic diversity of Rhizobium isolated from several countries around the world [4-9]. However the taxonomy of rhizobia is very diverse [10], molecular techniques based on the Polymerase Chain Reaction (PCR) provided easy and quick methods to microbial characterization $[11,12]$. The $16 \mathrm{~S}$ rRNA gene sequencing is an excellent tool for molecular characterization of the different isolates of Rhizobium [13,14].

The aims of this study were to characterize Rhizobium isolates collected from different Governorates in Egypt and to evaluate their tolerance of some heavy metals.

\section{Materials and Methods}

\section{Isolation of Rhizobia}

Eleven rhizobium isolates were collected from root nodules on broad bean (Vicia faba L.) plants from 11 different fields representing different geographic sites in Egypt according to the methods described by Vincent 1970. Table 1 and Figure 1 show the isolation sites and the name of the isolates.

\section{DNA extraction}

Total genomic DNA was extracted from bacterial cultures grown in Yeast Extract Mannitol media (YEM) as described by Shamseldin et al. [9]. The quality and quantity of DNA was characterized both spectrophotometrically and by $0.8 \%$ agarose gel. The DNA from all isolates produced clear sharp bands, indicating good quality of DNA. Samples were then diluted to $20 \mathrm{ng}$ DNA $\mu \mathrm{L}^{1}$ and kept at $-20^{\circ} \mathrm{C}$.

\section{Amplification of 16S rRNA gene}

The DNA of the Rhizobium isolates was amplified using the universal primers, fD1 (5' AGAGTTTGATCCTGG CTCAG 3') and rP2 (5' ACGGCTACCTTGTTA CGACTT 3') as described in Tsuzuki et al., [15]. The PCR reaction was performed in $50-\mu \mathrm{L}$ reaction volume containing $100 \mathrm{ng}$ DNA, $25 \mu \mathrm{L}$ Maxima Hot Start PCR Master Mix (Fermentas, Lithuania) and $20 \mu \mathrm{M}$ of forward and reverse primers. Amplifications were performed with the following conditions: initial denaturation at $95^{\circ} \mathrm{C}$ for $10 \mathrm{~min}, 35$ cycles of $95^{\circ} \mathrm{C}$ for $30 \mathrm{~s}, 58^{\circ} \mathrm{C}$ for 1 $\min , 72^{\circ} \mathrm{C}$ for $1 \mathrm{~min}$ and $10 \mathrm{~min}$ final extension at $72^{\circ} \mathrm{C}$.

\section{Partial 16S rRNA gene sequencing}

The PCR products for the eleven isolates were used in sequencing of the 16S rRNA gene from both strands using the same primers used in PCR amplification and Big Dye Terminator DNA analyzer (ABI) at Bioneer (Daejeon, Korea).

\section{Evaluation of heavy metals tolerance}

The eleven Rhizobium isolates were evaluated for their tolerance against three different heavy metals $(\mathrm{Cu}, \mathrm{Zn}$ and $\mathrm{Pb})$ on solid YEMA medium. The stock solutions of heavy metals $(\mathrm{mM})$ were filtered, sterilized and added to sterile agar as follows: $\mathrm{CuCl}_{2} \cdot 2 \mathrm{H}_{2} \mathrm{O} 0.5,1$ and

*Corresponding author: Khalid Abdel-lateif, Department of Genetics, Faculty of Agriculture, Menoufia University, Shibin El-Kom, Egypt, Tel: 002-010-048-02 E-mail: k_dein2001@yahoo.com

Received October 22, 2014; Accepted December 16, 2014; Published December 19, 2014

Citation: El-Zanaty AF, Abdel-lateif K, Elsobky M. (2014) Molecular Identification of Rhizobium Isolates Nodulating Faba Bean Plants in Egyptian Soils. J Bioprocess Biotech 5: 194 doi: 10.4172/2155-9821.1000194

Copyright: (c) 2014 El-Zanaty AF, et al. This is an open-access article distributed under the terms of the Creative Commons Attribution License, which permits unrestricted use, distribution, and reproduction in any medium, provided the original author and source are credited. 
2; $\mathrm{ZnSO}_{4} .7 \mathrm{H}_{2} \mathrm{O} 0.5,1$ and $2 ; \mathrm{Pb}\left(\mathrm{C}_{2} \mathrm{H}_{3} \mathrm{O}_{2}\right)_{2} .3 \mathrm{H}_{2} \mathrm{O} 0.5,1.0$ and 2.0. The plates were inoculated with $10^{-8}$ cells and the bacterial growth was evaluated after 7 days at $28^{\circ} \mathrm{C}[16,17]$. Isolates were considered resistant Isolates were considered resistant if growth was observed or sensitive if otherwise.

\section{Statistical analysis}

Phylogenetic and molecular evolutionary analyses were conducted using MEGA version 6 [18].

\section{Results and Discussion}

\section{Amplification and sequencing of 16S rRNA gene}

This work presents study on the genetic diversity of 11 Rhizobium leguminosarum symbiovar. Viciae isolates collected from different Vicia faba fields and representing several governorates in Egypt (Table 1 and Figure 1).

The 16S rRNA gene sequencing, which is widely used for molecular phylogeny of rhizobia $[13,14,19]$, was used as powerful tool to study the diversity and phylogenetic of Rhizobium isolates. The 16S rRNA gene was amplified using $\mathrm{fD} 1$ and $\mathrm{rP} 2$ primers as described by Tsuzuki et al. [15], and all the isolates yielded a single-fragment about $850 \mathrm{bp}$. After amplification the same primers were used for partial sequencing of $16 \mathrm{~S}$ rRNA region from the both sides. The alignment was done for all isolates sequences and the genetic diversity was estimated based on the number of base pairs substitution per site among all isolates (Table 2). The phylogenetic relationship analysis according to these data divided the isolates into two principal groups (Figures 2 and 3); the first group included isolates numbers 1,2,3,4,5,7,8,9,10 and 11 which were isolated from Menoufia, Menoufia, Gharbia, Gharbia, Gharbia, Behira, Dakhalia, Giza, Sharkyia and Ismailia governorates respectively. While the second group included only one isolate RL6 which was isolated from North Sinai Governorate. The genetic distance values between the isolates were variable and ranged from 0.02 to 0.8 . The lowest genetic distance values were obtained between isolate RL9 of Giza and RL10 of Sharkyia; the isolates RL4 of Gharbia and RL9 of Giza; the isolates RL1 of Menoufia and RL9 of Sharkyia with genetic values of 0.02, 0.03 and 0.05 respectively. While the highest genetic value was between RL6 of North Sinai and RL8 of Dakhalia.

It should be mentioned that the genetic distance values between isolates collected from different fields but from the same governorate for example Menoufia and Gharbia are low. In general, the values of genetic distances among the first group isolates are low. This may be due to the high conserved nature of the 16S rRNA gene sequences, so the sequences variability are limited and, second, the distance between the isolation sites of first group isolates ranged from 30 to $130 \mathrm{~km}$ so that it is possible that these isolates has originated from the same genetic background and the human activities like soil and plant transfer limited the genetic diversity of these isolates.

The second group included the isolate RL6 of north Sinai governorate which are located about of $300 \mathrm{~km}$ from isolation sites of other isolates and this may give explanation for the high genetic distances values with these isolates.

\section{Evaluation of heavy metals tolerance}

All of Rhizobium isolates were tested for their tolerance to heavy metals using concentrations of $0.5,1$ and $2 \mathrm{mM}$ of heavy metals $(\mathrm{Cu}$, $\mathrm{Pb}$ and $\mathrm{Zn}$ ). The isolates can be considered tolerant when the growth occurs in the presence of heavy metals. At the low concentration $(0.5$ $\mathrm{mM}), 73 \%, 100 \%$ and $91 \%$ of isolates were found to be resistant of $\mathrm{Cu}$, $\mathrm{Pb}$ and $\mathrm{Zn}$ respectively. Moreover at the concentration of $1 \mathrm{mmol}, 37 \%$, $80 \%$ and $55 \%$ of isolates were found to be tolerant of $\mathrm{Cu}, \mathrm{Pb}$ and $\mathrm{Zn}$ respectively. The resistance of Rhizobium isolates was recorded for copper, zinc and lead at concentration of $0.5,1 \mathrm{mM}$ of $\mathrm{Cu}$ and $\mathrm{Zn}$. this result is consistent with previous literature which indicated that Rhizobium is resistant to high concentrations of arsenate, zinc, copper, and mercury [20-22]. The ability to resist the heavy metals decreased with increase in concentration. At the highest concentration ( $2 \mathrm{mM})$, No growth was obtained with addition of $\mathrm{Zn}$ and Mn, however only $27 \%$ of isolates could survive with the same concentration of $\mathrm{Pb}$. Previous studies have shown that the increased concentrations of heavy metals can affect the growth, morphology and activities of microorganisms, including symbiotic $\mathrm{N}_{2}$ fixation [23-26]. Resistance of some tested isolates for the highest concentration of $\mathrm{Pb}$ is not understood [27]. One of explanations is that these isolates were isolated from soil polluted with $\mathrm{Pb}$ and have probably adapted to this environmental stress [28-31].

In general, the studied isolates showed a variable resistance against heavy metals and this will allow selecting of good candidates for genetic studies.

\begin{tabular}{|c|c|}
\hline Rhizobium isolates & Source \\
\hline RL1 & Menoufia governorate \\
\hline RL2 & Menoufia governorate \\
\hline RL3 & Gharbia governorate \\
\hline RL4 & Gharbia governorate \\
\hline RL5 & Gharbia governorate \\
\hline RL6 & North Sinai governorate \\
\hline RL7 & Behira governorate \\
\hline RL8 & Dakhalia governorate \\
\hline RL9 & Giza governorate \\
\hline RL10 & Sharkya governorate \\
\hline RL11 & Ismailia governorate \\
\hline
\end{tabular}

Table 1: Rhizobium isolation governorates

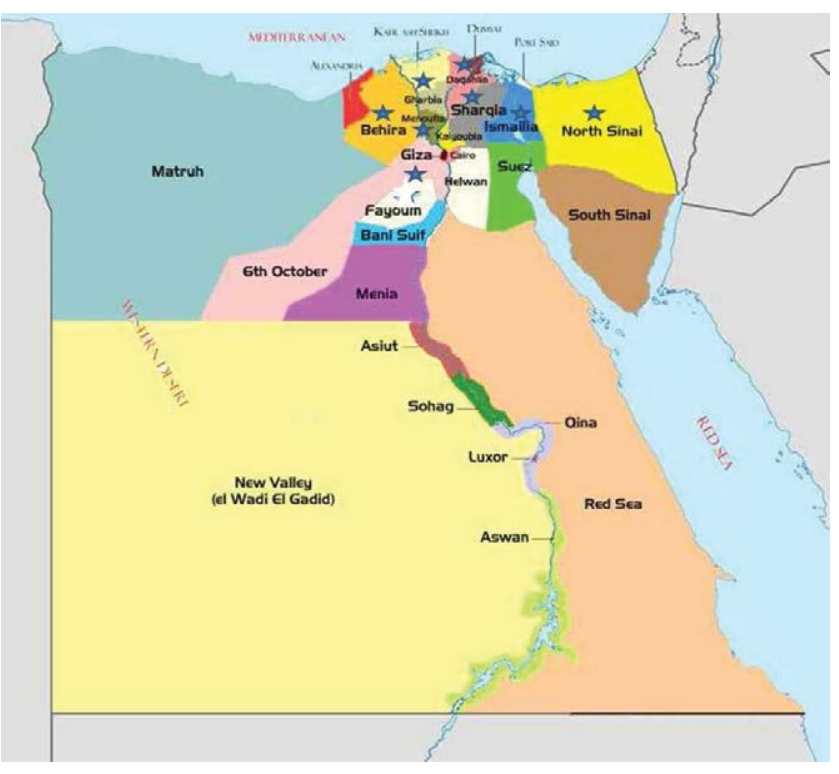

Figure 1: Map show distribution of Rhizobium isolation sites in Egypt 
Citation: El-Zanaty AF, Abdel-lateif K, Elsobky M. (2014) Molecular Identification of Rhizobium Isolates Nodulating Faba Bean Plants in Egyptian Soils. J Bioprocess Biotech 5: 194 doi: 10.4172/2155-9821.1000194

Page 3 of 4

\begin{tabular}{|c|c|c|c|c|c|c|c|c|c|c|c|}
\hline RL11 & RL10 & RL9 & RL8 & RL7 & RL6 & RL5 & RL4 & RL3 & RL2 & RL1 & Isolates \\
\hline & & & & & & & & & & 0.0 & RL1 \\
\hline & & & & & & & & & 0.00 & 0.26 & RL2 \\
\hline & & & & & & & & 0.00 & 0.12 & 0.27 & RL3 \\
\hline & & & & & & & 0.00 & 0.24 & 0.27 & 0.08 & RL4 \\
\hline & & & & & & 0.00 & 0.25 & 0.04 & 0.14 & 0.28 & RL5 \\
\hline & & & & & 0.00 & 0.61 & 0.53 & 0.59 & 0.53 & 0.52 & RL6 \\
\hline & & & & 0.00 & 0.6 & 0.21 & 0.26 & 0.2 & 0.22 & 0.29 & RL7 \\
\hline & & & 0.00 & 0.34 & 0.8 & 0.22 & 0.27 & 0.24 & 0.28 & 0.25 & RL8 \\
\hline & & 0.00 & 0.31 & 0.25 & 0.54 & 0.25 & 0.03 & 0.24 & 0.24 & 0.05 & RL9 \\
\hline & 0.00 & 0.02 & 0.28 & 0.26 & 0.53 & 0.24 & 0.03 & 0.24 & 0.26 & 0.07 & RL10 \\
\hline 0.00 & 0.38 & 0.36 & 0.3 & 0.37 & 0.71 & 0.2 & 0.4 & 0.21 & 0.31 & 0.38 & RL11 \\
\hline
\end{tabular}

Table 2: Number of base substitution per site between 11 Rhizobium legurninosarum isolates as obtained by Mega 6

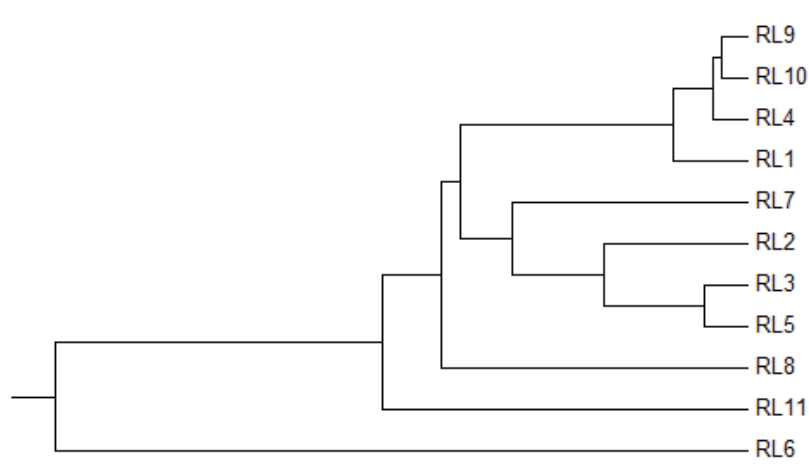

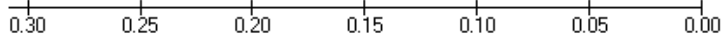

Figure 2: Phylogenetic relationship between 11 Rhizobial isolates using MEGA6 program based on 16S rRNA gene sequence data

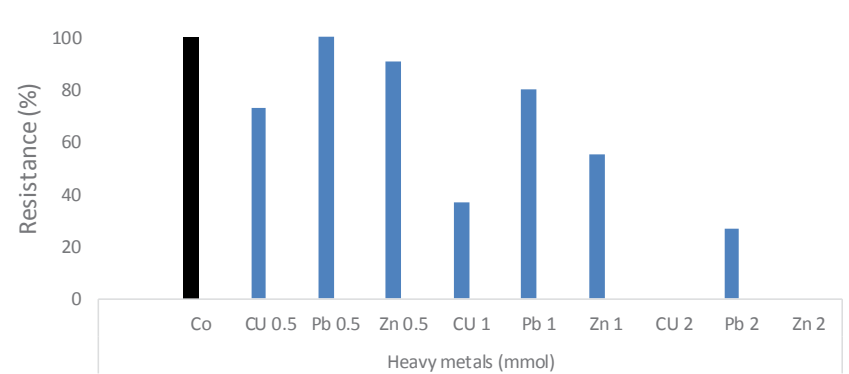

Figure 3: Resistance of Rhizobial isolates against heavy metals concentrations $(0.5,1$ and $2 \mathrm{mM})$ as compared with control (Co)

\section{References}

1. Doyle JJ (2001) Leguminosae. Encyclopedia of Genetics. Brenner S, Miller JH (Editors), Academic, San Diego, USA, 1081-1085.

2. Kinzig AP, Socolow RH (1994) Is nitrogen fertiliser use nearing a balance-reply. Physics Today 14: 24-35.

3. Doyle JJ (1998) Phylogenetic perspectives on nodulation: evolving views of plants and symbiotic bacteria. Trends in Plant Science 3: 473-478.

4. Mutch LA, Tamimi SM, Young JPW (2003) Genotypic characterization of rhizobia nodulating Vicia faba from soils of Jordan: a comparison with UK isolates. Soil Biol \& Bioch 35: 709-714.

5. Mutch LA, Young PW (2004) Diversity and specificity of Rhizobium leguminosarum symbiovar viciae on wild and cultivated legumes. Molecular Ecology 13: 2435-2444.

6. Moschetti G, Peluso AL, Protopapa A, Anastasio M, Pepe O, et al. (2005) Use of nodulation pattern, stress tolerance, nodC amplification, RAPDPCR and RFLP-16S rDNA analysis to discriminate genotypes of Rhizobium leguminosarum biovar viciae. Systematic and Applied Microbiology 28: 619-631.

7. Vessey JK, Chemining'wa GN (2006) The genetic diversity of Rhizobium leguminosarum bv. viciae in cultivated soils of the eastern Canadian prairie. Soil Biology and Biochemistry 38: 153-163.

8. Tian CF, Wang ET, Han TX, Sui XH, Chen WX (2007) Genetic diversity of rhizobia associated with Vicia faba in three ecological regions of China. Archives of Microbiology 188: 273-282.

9. Shamseldin A, El-Saadani M, Sadowsky MJ, Sun An C (2009) Rapid identification and discrimination among Egyptian genotypes of Rhizobium leguminosarum bv. viciae and Sinorhizobium meliloti nodulating faba bean (Vicia faba L.) by analysis of nodC, ARDRA, and rDNA sequence analysis. Soil Biology \& Biochemistry 41: 45-53.

10. Wolde-Meskel E, Terefework Z, Lindstrom K, Frostegard A (2004) Metabolic and Genomic Diversity of Rhizobia Isolated from Field Standing Native and Exotic Woody Legumes in Southern Ethiopia. Syst Appl Microbiol 27: 603-611.

11. Adiguzel A (2006) Molecular characterization of thermophilic bacteria isolated from water samples taken from various thermal plants. PhD Thesis, Ataturk University, Graduate School at Natural and Applied Sciences, Erzurum, Turkey.

12. Shoukry AA, Khattab AA, Abou-Ellail M, El-shabrawy H (2013) Molecular and biochemical characterization of new Rhizobium leguminosarum bio viciae strains isolated from different located of Egypt. Journal of Applied Sciences Research 9: 5864-5877.

13. Ismail M, El-Zanatay AM, Eissa RA, Hewedy OA (2013) Genetic Diversity of Rhizobium leguminosarum as Revealed by $16 \mathrm{~S}$ rRNA Gene Sequence. American-Eurasian J Agric \& Environ Sci 13: 797-801.

14. Silva FV, Simões-Araújo JL, Silva Júnior JP, Xavier GR, Rumjanek NG (2012) Genetic diversity of Rhizobia isolates from Amazon soils using cowpea (Vigna unguiculata) as trap plant. Brazilian Journal of Microbiology: 682-691.

15. Tsuzuki C, Brunheira ATP, Mayer MPA (2008) 16 S rRNA Region Based PCR protocol for identification and subtyping of Parvimonas micra. Braz J Microbio 39: $605-607$.

16. Ausili $P$, Borisov A, Lindblad $P$, Martensson A (2002) Cadmium affects the interaction between peas and root nodule bacteria. Acta Agric Scand Sect B Soil Plant Sci 52: 8-17.

17. Chaudri AM, McGrath SP, Giller KE (1992) Metal tolerance of isolates of Rhizobium leguminosarum biovar Trifolii from soil contaminated by past applications of sewage sludge. Soil Biol Biochem 24: 83-88.

18. Tamura K, Stecher G, Peterson D, Filipski A, Kumar S (2013) MEGA6 Molecular Evolutionary Genetics Analysis version 6.0. Molecular Biology and Evolution 30: 2725-2729

19. Menna P, Hungria M, Barcellos FG, Bangel EV, Hess PN, et al. (2006) Molecular phylogeny based on the 16S rRNA gene of elite rhizobial strains used in Brazilian commercial inoculants. Syst Appl Microbiol 29: 315-332.

20. Carrasco JA, Armario P, Pajuelo E, Burgos A, Caviedes MA, et al. (2005) Isolation and characterisation of symbiotically effective Rhizobium resistant to arsenic and heavy metals after the toxic spill at the Aznalcóllar pyrite mine. Soil Biol Biochem 37: 1131-1140.

21. Cenap Cevheri, Çiğdem Küçük, Esat Çetin (2011) Fungicide, antibiotic, heavy metal resistance and salt tolerance of root nodule isolates from Vicia palaestina. African Journal of Biotechnology 10: 2423-2429. 
Citation: El-Zanaty AF, Abdel-lateif K, Elsobky M. (2014) Molecular Identification of Rhizobium Isolates Nodulating Faba Bean Plants in Egyptian Soils. J Bioprocess Biotech 5: 194 doi: 10.4172/2155-9821.1000194

Page 4 of 4

22. Berrada H, Nouioui I, Houssaini MI, El Ghachtouli N, Gtari M, et al. (2012) Phenotypic and genotypic characterizations of rhizobia isolated from root nodules of multiple legume species native of Fez, Morocco. African Journal of Microbiology Research 6: 5314-5324.

23. Shi W, Bischoff M, Turco R, Konopka A (2002) Long-termeffects of chromium and lead upon the activity of soil microbial communities. Appl Soil Ecol 21: 169-177.

24. Lakzian A, Murphy P, Turner A, Beynon JL, Giller KE (2002) Rhizobium leguminosarum bv. viciae populations in soils with increasing heavy metal contamination: abundance, plasmid profiles, diversity and metal tolerance. Soil Biology and Biochemistry 34: 519-529.

25. Khan M, Scullion J (2002) Effects of metal ( $\mathrm{Cd}, \mathrm{Cu}, \mathrm{Ni}, \mathrm{Pb}$ or $\mathrm{Zn}$ ) enrichment of sewage-sludge on soil microorganisms and their activities. Appl Soil Ecol 20: 145-155.

26. McGrath SP, Brookes PC, Giller KE (1988) Effects of potentially toxic elements in soil derived from past applications of sewage sludge on nitrogen fixation by
Trifolium repens L. Soil Biology and Biochemistry 20: 415-424.

27. Ogutcu H, Algur OF, Elkoca E, Kantar F (2008) The determination of symbiotic effectiveness of rhizobium strains isolated from wild chickpeas collected from high altitudes in Erzurum. Turk J Agric Forest Sci 32: 241-248.

28. Küçük Ç, Kıvanç M, Kınacı E (2006) Characterization of Rhizobium sp. isolated from bean. Turk J Biol 30: 127-132.

29. Rincón A, Arenal F, González I, Manrique E, Lucas MM, Pueyo JJ (2007) Diversity of Rhizobial Bacteria Isolated from Nodules of the Gypsophyte Ononis tridentata L. Growing in Spanish Soils. Microb Ecol 56: 223-233.

30. Pereira SIA, Lima AIG, Figueira EMAP (2006) Heavy metal toxicity in Rhizobium leguminosarum biovar viciae isolated from soils subjected to different sources of heavy-metal contamination: Effects on protein expression. Applied Soi Ecology 33: 286-293.

31. Vincent JM (1970) A manual for the practical study of the root nodule bacteria International Biological Programme hand-book no. 15. Blackwell, Oxford. 